\title{
Effect of Supplementing Rumen Protected Amino Acids on the Milk Protein Content of Cows Fed Calcium Soap of Fatty Acids
}

\author{
Takamitsu Ain*, Masanobu TAMAKI', Kyouji SHIRAISHI', \\ Hirotoshi Hayasawa ${ }^{3}$ and Shuzo IsHid ${ }^{4}$ \\ Kyushu National Agricultural Experiment Station, \\ Nishigoshi-machi, Kumamoto-ken 861-11 \\ ${ }^{1}$ Okinawa Prefectural Livestock Experiment Station, \\ Nakijin-mura, Okinawa-ken 905-04 \\ ${ }^{2}$ Saga Prefectural Livestock Experiment Station, \\ Yamauchi-machi, Saga-ken 849-23 \\ ${ }^{3}$ Food Research and Development Laboratory, Morinaga \\ Milk Industry Co., Ltd. Zama-shi 228 \\ "Taiyo Yushi Co., Ltd. Kanagawa-ku, Yokohama-shi 221 \\ * Present address; Chugoku National Agricultural \\ Experiment Station, Ohda-shi 694 \\ ${ }^{1}$ For example, as set out in the milk price regulations of the \\ Kumamoto Prefectural Dairy Co-operative Association
}

(Received October 8, 1993)

Key words : protected amino acids, calcium soap, milk protein, dairy cows

Supplementing the diet of dairy cows with calcium soap of fatty acids (CS) is common in Kyushu, the southernmost major island of Japan, to alleviate the decrease in milk yields and milk fat (MF) contents during hot summers. The increase in milk yields and MF contents caused by supplementing $330 \mathrm{~g} \mathrm{CS/}$ day $^{3)}$ averaged $0.25 \mathrm{~kg} /$ day and $0.30 \%$, respectively, whereas a slight reduction in the milk protein (MP) content was observed ${ }^{3,8,10,17)}$.
This reduction in MP content is probably due to the dilution effect, because, commonly, the rate of increase in milk yield exceeds that of the MP yield.

SNF content, in which MP is one of major constituents, is a concern of Kyushu farmers because milk price is based partly on the SNF conten $t^{1}$. Therefore, it is necessary to find measures that will prevent the reduction in the MP content when dairy cows are fed CS.

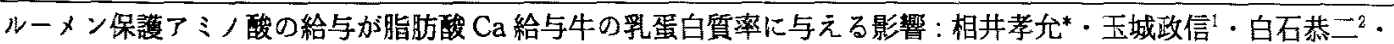
早澤宏紀 ${ }^{2}$ - 石田修三4（農林水産省九州農業試験場，熊本県西合志町 861-11 ${ }^{1}$ 沖縄県畜産試駩場，沖䋲県今帰仁

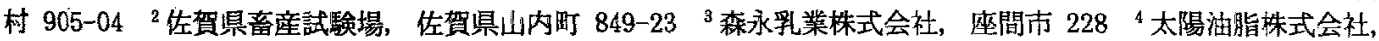
横浜市神奈川区 221）*現所属 : 農林水産省中国農業試験場, 大田市 694 
An insufficient supply of high protein feed seems to cause a reduction in the MP content, especially when the cow has a deficiency in the essential amino acids that form milk protein. Some papers ${ }^{5,8,15)}$ reported that supplementing the cows' diet with rumen protected essential amino acids, such as Met and Lys could elevate the MP content.

The object of this study was to examine whether the reduction in the MP content of cows fed CS could be alleviated by supplementing their diet with rumen protected amino acids (RPAA).

\section{Materials and Methods}

CS and RPAA: The CSs prepared from palm oil and tallow were obtained from Taiyo Yushi Co., Ltd. (Yokohama) and Nippon Soda Co., Ltd. (Tokyo), respectively. Their fatty acid compositions were as follows; myristic, $1.0,6.3 \%$, palmitic, $40.1,27.4 \%$, stearic, $5.3,14.1 \%$, oleic, $39.3,49.6 \%$, linoleic, $8.8,2.5 \%$ and others, $5.1,0.1 \%$ respectively.

RPAA obtained from Nippon Soda Co, Ltd. was mixed as follows; The Met (DLmethionine) was mixed into the CS powder of tallow, while the Lys (L-lysine monohydrochloride) was mixed into the CS powder of palm oil. The mixtures were then firmly cast into a cylindrical shapes $(2.1 \mathrm{~mm}$ diameter, $3.0 \mathrm{~mm}$ length). The former contained $85.5 \%$ CS prepared from tallow, $12.8 \% \mathrm{Met}$ and $1.7 \%$ binder while the latter contained $83.3 \% \mathrm{CS}$ from palm oil and $16.7 \%$ Lys. The ruminal protection and postruminal release of Met in the former were 97 and 84\% respectively, 62 and $44 \%$ respectively for Lys. These values were determined by Nippon Soda Co., Ltd. In this Experiment, RPAA is defined as Met and Lys only, excluding CS by which the amino acids are protected.

Experimental procedures: Experiments 1,2 and 3 were conducted from late July through early September, from early July through mid August and from mid July through late
August at Saga, Okinawa Prefectural Livestock Experiment Station and Kyushu National Agricultural Experiment Station, respectively.

Nine primiparous (average body weight, 461 $\mathrm{kg}$, Experiment 1), 6 multiparous ( $569 \mathrm{~kg}$, Experiment 2) and 6 multiparous $(631 \mathrm{~kg}$, Experiment 3) lactating Holstein cows were used in a triplicated $3 \times 3$ or a replicated $3 \times 3$ Latin square designed experiment using 14 day periods. Data collected from the three stations were analyzed using a combination fo a Latin square design and a blook design ${ }^{18)}$. The cows were in early lactation in Experiment 1 and in mid lactation in Experiments 2 and 3 . All cows received three treatments ; the first was a conventional basal $\operatorname{diet}(\mathrm{C})$, the second was an addition of $225 \mathrm{~g}$ CS to the basal $\operatorname{diet}(\mathrm{T} 1,104 \mathrm{~g}$ $\mathrm{CS}$ from tallow and $121 \mathrm{~g}$ CS from palm oil in addition to the basal diet) and the third was $T$ 1 plus RPAA (T 2, $104 \mathrm{~g}$ CS from tallow $121 \mathrm{~g} \mathrm{CS}$ from palm oil, $17 \mathrm{~g}$ Met and $24 \mathrm{~g}$ Lys in addition to the basal diet).

Rations: In Experiment 1, the basal diet was a total mixed ration consisting of $29.7 \%$ Italian ryegrass silage, $6.8 \%$ alfalfa haycube, $6.8 \%$ beet pulp, $6.8 \%$ rice straw, $21.6 \%$ formula feed for lactation, $5.4 \%$ barley and $6.8 \%$ soybean meal (on a fresh basis), which met the nutrient requirements for maintenance and milk yield according to Japanese Feeding Standard for dairy cattle (JFS).

In Experiment 2, the basal diet consisted of $5.5-9.8 \mathrm{~kg}$ of formula feed for lactation, $2.5-3.0$ $\mathrm{kg}$ of beet pulp, $3.0 \mathrm{~kg}$ of barley, $1.0 \mathrm{~kg}$ of alfalfa haycube and $14.6-17.1 \mathrm{~kg}$ of guineagrass silage (on a fresh basis), which met the nutrient requirements for maintenance and milk yield according to JFS.

In Experiment 3, cows were offered $7.2-9.1 \mathrm{~kg}$ of formula feed for lactation, $2.0-3.0 \mathrm{~kg}$ of beet pulp, $1.7-1.8 \mathrm{~kg}$ of soybean meal and $1.0 \mathrm{~kg}$ of alfalfa haycube to meet or exceed slightly the nutrient requirements for milk yield based on JFS. In addition, corn haylage was fed $a d$ 
Milk Protein Respond to RPAA Supplement

\section{libitum to cows.}

Prior to feeding of the diets, the CS or CS plus RPAA was fully mixed with the formula feed or total mixed ration.

In all Experiments, the crude protein and TDN content (of the diets) were 15-17\% and 67 $-69 \%$ of DM, respectively. Especially in Experiment 3 , those contents were corrected by adding soybean meal to the formula feed, after first predicting the roughage intakes and crude protein contents.

In Experiments 1 and 2, dry matter intake was determined for the last 5 days of each treatment.

In all Experiments, body weights were determined on the 11th and 13th day of each treatment.

Analysis of milk samples: In all Experiments, milk yield was recorded daily and milk samples were collected at morning and evening milking times for the last 5 days of each treatment. The analysis of the milk composition and milk fatty acid composition were performed according to the previous paper ${ }^{2)}$, except for the analysis of the milk composition in Experiment 3 where a Foss Milko-scan $133 \mathrm{~B}$ (Foss Electric, Hillerod, Denmark) was used.

\section{Results and Discussion}

There was no problem with the palatability of CS and CS plus RPAA as the diets containing the supplements (1.3 to $1.8 \%$ of the dietary DM) were almost completely ingested by the cows.

Dry matter intakes, which ranged from 14.6 to $14.8 \mathrm{~kg} /$ day and from 17.9 to $18.6 \mathrm{~kg}$ /day in Experiments 1 and 2, respectively, were unaffected by treatments.

No significant changes in body weights were observed.

SCHAUFF and $\mathrm{C}_{\mathrm{LARK}}{ }^{16)}$ reported that $\mathrm{CS}$ could comprise up to 6 percentage of the dietary DM without deleterious effects on ruminal fermentation and digestibilities of most nutrients. The authors also demonstrated that the metab- olite contents in the blood serum of cows were unaffected by supplementing up to $420 \mathrm{~g} \mathrm{CS} /$ day ${ }^{1}$.

Cows consuming the diet containing CS or CS plus RPAA produced more milk than those consuming the conventional diet $(p<0.05)$. Our papers ${ }^{1,4)}$ and other papers ${ }^{11,47}$ have demonstrated that supplementing CS to cows increased their energy intake and subsequently their milk yields, although the increased milk yield amounts varied with different researchers. In this Experiment, the increase in milk yield reached $1.1 \mathrm{~kg} /$ day when cows were given $225 \mathrm{~g} \mathrm{CS} / \mathrm{cow} /$ day (Table 1 ).

There was no difference in milk yield between $\mathrm{T} 1$ and $\mathrm{T} 2$. This fact indicates that the milk yield was unaffected by supplementing RPAA to diet containing CS. Some papers ${ }^{7.13 .14)}$ also reported that supplementing RPAA has no effect on milk yields.

The MP yield was greatest in the cows fed a diet CS plus RPAA $(p<0.01)$. MP yields increased by $20 \mathrm{~g}$. and $40 \mathrm{~g} /$ day for $\mathrm{T} 1$ and $\mathrm{T} 2$, respectively, compared with that for $\mathrm{C}$. There was a significant difference between $\mathrm{T} 1$ and $\mathrm{T}$ $2(p<0.05)$.

The MP content tended to decrease for $\mathrm{T} 1$ and increase for $\mathrm{T} 2$ compared with that for $\mathrm{C}$, and it was 0.11 percentage unit higher for $\mathrm{T} 2$ than for $T 1(p<0.05)$ although no significant difference was found between $\mathrm{T} 2$ and $\mathrm{C}$. The SNF content was lower for $\mathrm{T} 1$ than for either $\mathrm{C}$ or $\mathrm{T} 2(\mathrm{p}<0.05)$. The major reason for the decrease in the SNF content is thought to be due to the decrease in the MP content.

Some studies ${ }^{3,8,10,17)}$ have demonstrated that after fat was added to the cows' diets, the MP yield increased while its content decreased. Commonly, the addition of fat to diets causes MP to be reduced by 0.1 to 0.2 percentage units. In this Experiment, the MP content tended to decrease by 0.06 percentage unit after the conventional diets were supplemented with $\mathrm{CS}$.

As shown in Table 1 , the increasing rate of milk yield resulting from the addition of CS 
AlI, Tamaki, Shiraishi, Hay asawa and Ishida

Table 1. Effects of supplementing rumen protected amino acids to the dairy cows fed calcium soap of fatty acids on milk yield and milk composition

\begin{tabular}{|c|c|c|c|c|c|}
\hline & \multirow{2}{*}{ Control } & \multirow{2}{*}{ Treatment 1} & \multirow{2}{*}{ Treatment 2} & \multicolumn{2}{|c|}{ 1.s.d. } \\
\hline & & & & $\mathrm{p}=0.05$ & $\mathrm{p}=0.01$ \\
\hline \multicolumn{6}{|l|}{ Production } \\
\hline Milk (kg/day) & $21.0^{\mathrm{b}}$ & $22.1^{\mathrm{a}}$ & $22.0^{\mathrm{a}}$ & 0.9 & 1.5 \\
\hline Fat (g/day) & $726^{\mathrm{b}}$ & $788^{a}$ & $802^{\mathrm{a}}$ & 29 & 48 \\
\hline Protein (g/day) & $650^{c}$ & $670^{\circ}$ & $690^{\circ}$ & 15 & 26 \\
\hline \multicolumn{6}{|l|}{ Milk composition } \\
\hline Fat & $3.47^{b}$ & 3. $59^{\mathrm{ab}}$ & 3. $66^{\mathrm{a}}$ & 0.17 & 0.28 \\
\hline Protein & 3. $08^{\mathrm{ab}}$ & $3.02^{\mathrm{b}}$ & $3.13^{\mathrm{a}}$ & 0.09 & 0.15 \\
\hline SNF & 8. $66^{\mathrm{a}}$ & $8.56^{b}$ & $8.63^{\mathrm{a}}$ & 0.07 & 0.12 \\
\hline Total solids & 12.13 & 12.15 & 12.29 & 0.22 & 0.36 \\
\hline \multicolumn{6}{|c|}{$\begin{array}{l}\text { Milk fatty acid } \\
\text { composition }(\%)^{1}\end{array}$} \\
\hline $\mathrm{C}_{4}-\mathrm{C} 14$ group & $27.1^{\mathrm{b}}$ & $24.3^{a}$ & $25.2^{a}$ & 1.7 & 2.9 \\
\hline C 16 group & 33.5 & 32.7 & 32.5 & 1.8 & 3.0 \\
\hline C 18 group & $29.9^{\mathrm{b}}$ & $34.9^{\mathrm{a}}$ & 34. $0^{a}$ & 2.8 & 4.6 \\
\hline \multicolumn{6}{|l|}{$\begin{array}{l}\text { Milk fatty acids } \\
\text { production }(\mathrm{g})\end{array}$} \\
\hline $\mathrm{C} 14: 0$ & 82 & 81 & 83 & 7 & 12 \\
\hline $\mathrm{C} 16: 0$ & 217 & 226 & 227 & 13 & 21 \\
\hline$C 18: 0$ & $55^{b}$ & $66^{8}$ & $66^{a}$ & 9 & 14 \\
\hline C $18: 1$ & $127^{\mathrm{b}}$ & $166^{\mathrm{a}}$ & $162^{\mathrm{a}}$ & 16 & 26 \\
\hline $\mathrm{C} 18: 2$ & $13^{c}$ & $15^{\mathrm{b}}$ & $16^{\mathrm{a}}$ & 1 & 2 \\
\hline C 4-C 14 group & 182 & 176 & 187 & 16 & 26 \\
\hline C 16 group & 227 & 236 & 236 & 11 & 18 \\
\hline C 18 group & $199^{\circ}$ & $251^{a}$ & $248^{a}$ & 19 & 31 \\
\hline Body weight $(\mathrm{kg})$ & 557 & 552 & 552 & 11 & 19 \\
\hline
\end{tabular}

a. b.c Numbers with different superscripts in the same row differ $(p<0.05)$.

1 : The sum of total fatty acids on a chromatogram, calculated as $100 \%$.

was $5.0 \%[(22.1 \mathrm{~kg}-21.0 \mathrm{~kg}) \times 100 / 22.1 \mathrm{~kg} \fallingdotseq$ $5.0 \%]$, whereas the rate of MP was $3.0 \%$ [ $(670 \mathrm{~g}$ $-650 \mathrm{~g}) \times 100 / 670 \mathrm{~g}=3.0 \%]$, that is, the reason for the decrease on the MP content was due to the former being in excess of the latter (the dilution effect). However, the deperssion in the MP content can be prevented by the addition of RPAA to lactation diets containing CS because the rate of increase in MP yield [ $(690 \mathrm{~g}$ $-650 \mathrm{~g}) \times 100 / 690 \mathrm{~g} \div 5.8 \%)]$ exceeded that of the milk yield $[(22.0 \mathrm{~kg}-21.0 \mathrm{~kg}) \times 100 / 22.0 \mathrm{~kg} \doteqdot$ $4.5 \%$ ]. Some papers ${ }^{5,8,15}$ also reported that supplementing the cows' diet with rumen pro- tected essential amino acids, such as Met and Lys could elevate the MP content.

The MF yield and its content increased ( $p<$ 0.01 and $p<0.05$ ) after supplementing CS plus RPAA, and the MF yield also increased $(\mathrm{p}<$ 0.01) with the CS addition, although the increase in MF content was not significant. When cows received diets containing CS plus RPAA, about one third of the ingested CS seemed to transfer into milk fat (Table 1).

The MF yield tended to be higher for $\mathrm{T} 2$ than for $T 1$, although the difference was not significant. This fact was consistent with the 
Milk Protein Respond to RPAA Supplement

results of other papers ${ }^{5,6)}$, suggesting that supplementing RPAA have the advantage of being able to stimulate the fat metabolism of mammary gland ${ }^{6,12}$, where ingested CS is converted into $M F$.

Among the milk fatty acid groups, the $\mathrm{C} 18$ group content increased ( $p<0.01$ or $P<0.05$ ) by supplementing CS or CS plus RPAA, whereas the $C 4-C 14$ group decreased $(p<0.05)$ and the $C$ 16 group tended to decrease.

Among the milk fatty acids, $\mathrm{C} 18: 1$ production predominantly increased $(\mathrm{p}<0.01)$ and $\mathrm{C} 18$ $: 0$ also increased $(p<0.05)$, whereas $C 16: 0$ remained almost unchanged. These results suggest that C18:1, of which CS (prepared from palm oil and tallow) is a rich source, transferred effectively into $M F$.

According to GRUMMER ${ }^{9)}$, the C18 group content increased with the addition of fat to the diet, whereas $\mathrm{C} 16$ group decreased relatively, because de novo synthesis of $\mathrm{C} 16: 0$ was suppressed in the mammary secretory tissue. In addition, the milk fatty acid composition is largely dependent on a variety of fat which has been added to the diet.

In conclusion, to prevent a detrimental effect on the MP content following the supplementation of CS, RPAA was added to the lactaion diets containing $C S$. This had the advantage of improving MP content and hence the SNF content, in comparison to the supplementation of CS alone.

\section{References}

1) Ail, T., M. Kurihara, S. Kume, M. Tomita and H. HAYASAWA, The effect of feeding calcium soap of fatty acids and sodium acetate on the physiological responses of dairy cows. Jpn. J. Zootech. Sci., 61 : 959-962. 1990.

2) AIr, T., M. KuRIHARA and S. IsHIDA, Increase in $\alpha$-linolenic acid in milk fat by feeding the calcium soap of fatty acids prepared from linseed oil. Anim. Sci. Technol. (Jpn.), 62 : 58-62. 1991.

3) AII, T., M. KuRihaRa, K. ShiRaISHI, M. TAmakI and Y. Chiba, The effect of feeding calcium soap of fatty acids on milk yield, milk compo- sition and economical evaluation in dairy cows. Anim. Sci. Technol. (Jpn.), 62 : 636-644. 1991.

4) Ail, T., M. Muraoka, F. Terada, T. Tubokawa, S. IsHidA and H. HAYASAWA, Effects of a combination of an evaporative cooling system and calcium soap of fatty acid feeding on the milk yield, milk composition and body temperature of dairy cows during summer. Anim. Sci. Technol. (Jpn.), $64:$ 470-473. 1993.

5) CANAle, C.J., L.D. Muller, H.A. McCAhon, T.J. WhiTSEL, G.A. VARGA and M.J. LORMORE, Dietary fat and ruminally protected amino acids for high producing dairy cows. J. Dairy Sci., $73: 135-141.1990$.

6) Chalupa, W., Discussion of protein symposium. J. Dairy Sci., 67 : 1134-1146. 1984.

7) Chow, J.M., E.J. DePeters and R.L. BAlDwin, Effect of rumen-protected methionine and lysine on casein in milk when diets high in fat or concentrate are added. J. Dairy Sci., 73 : 1051 $-1061.1990$.

8) DePeters, E.J. and J.P. CANT, Nutritional factors influencing the nitrogen composition of bovine milk: A review. J. Dairy Sci., 75 : 2043-2070. 1992.

9) Grummer, Ric. R., Effect of feed on the composition of milk fat. J. Dairy Sci., $74: 3244-3257$. 1991.

10) KinKaid R.L. and J.D. CronRath, Effects of added dietary fat and amino acids on performance of lactating cows, J. Dairy Sci, $76: 1601-$ 1606. 1993.

11) NaKano, M., E. Yamamoto, K. AKimoto, I. Notsuke, Feeding calcium soap of fatty acids to dairy cows. Jap. J. Livest. Management, 26 : 36-37. 1990. (in Japanese)

12) Oldham, J.D., Protein-energy interrelationships in dairy cows. J. Dairy Sci., $67: 1090-1114$. 1984.

13) Papas, A.M., C.J. Sniffen and T.V. Muscato, Effectiveness of rumen-protected methionine for delivering methionine postruminally in dairy cows. J. Dairy Sci., $67: 545-552.1984$.

14) Papas, A.M., J.L. VICINI, J.H. Clark and S. PEIRCE-SANDNER, Effect of rumen-protected methionine on plasma free amino acids and production by dairy cows. J. Nutr., $114: 2221$ 2227. 1984.

15) Rogers, J.A., U. KRISHNAMOORThy and C.L. SNIFFEN, Plasma amino acids and milk protein production by cow fed rumen-protected methionine and lysine. J. Dairy Sci., 70 : 789- 
798. 1987.

16) SchaufF, D.J. and J.H. ClaRK, Effects of feeding diets containing calcium salts of longchain fatty acids to lactating dairy cows. J. Dairy Sci., 75 : 2990-3002. 1992.

17) Sklan, D., R. Ashkenaz, A. Braun, A. Devorin and K. TABORI, Fatty acids, calcium soaps of fatty acids, and cottonseeds fed to high yielding cows. J. Dairy Sci., 75 : 2463-2472. 1992.

18) Yoshida, M., Design of Experiments for Animal Husbandry. 111-114. Yokendo. Tokyo. 1975. 